УДК 342.9

DOI https://doi.org/10.32844/2618-1258.2019.6.2

СОРОЧАН Д.А.

\title{
БУЛІНГ: ПОНЯТТЯ, ІСТОРІЯ ІСНУВАННЯ, ХАРАКТЕРИСТИКА
}

Досліджуючи поняття булінгу, можна зрозуміти, наскільки такий прояв поведінки з боку неповнолітніх осіб актуальний для України. Агресія неповнолітніх значно зростає, що виражається у знущанні як моральному, так і у фізичному плані над особами такого самого віку, меншого або старшого. Особи, які тією чи іншою мірою проявляють булінг на стадії формування своєї психіки, в дорослому віці стають дуже жорстокими злочинцями, тобто булінг супроводжується скоєнням різних правопорушень і підвищенням криміногенної обстановки загалом. Тому це питання необхідно підіймати як у теоретичному, так і у практичному плані. Аналіз наукової літератури, нормативно-правової бази дозволив встановити та розкрити поняття булінгу, його співвідношення з агресією та насильством. Спираючись на погляди окремих авторів, розкрито сутність і зміст поняття булінгу. Визначено учасників такої поведінки, основні риси булінгу. 3'ясовано, що агресивну жертву описують дуже агресивною й емоційно нестабільною. У ситуації булінгу вона характеризуються комбінацією із тривожних і агресивних реакцій, легко дратується і впадає у стан гніву, піддається на провокації. Її швидко охоплюють неприязні почуття у провокаційній ситуації, вона стає нездатною правильно інтерпретувати наміри або висловлювання. Агресивні жертви відрізняються від булерів і покірних жертв тим, що здатні проявити агресивні дії, але не використовують їх як інструмент для досягнення мети, не вибирають систематично для агресії більш слабких осіб, а вдаються до неї внаслідок втрати самовладання. Визначено, що булінг - це соціальна, емоційна поведінка особи або групи осіб, яка може виражатися в антисоціальному аспекті, має вербальні та невербальні способи вираження, де існує невідповідність сили та влади, що ставить жертву (жертв) у становище у якому вона (вони) не здатна себе захистити, має тривалий характер, результатом якого $€$ настання негативних наслідків щодо жертви (жертв) та отримання задоволення від своїх діянь агресором (агресорами).

Ключові слова: булінг, агресія, насильство, неповнолітня особа.

Exploring the concept of bulling, it becomes clear how relevant such a manifestation of his behavior on the part of minors is relevant for Ukraine. Juvenile aggression has significant growth, manifested in bullying both morally and physically, over persons of the same age, less or older. Those persons who, to one degree or another, exhibit bulling at the stage of forming their psyche, in adulthood, are, above all, very violent criminals. That will be followed by committing different kinds of offenses and increasing the criminal situation as a whole. Therefore, this question must be raised both theoretically and in the future and in practical terms, to prevent the manifestation of bulling. During the analysis of the scientific literature, the normative and legal framework was established and revealed the concept of bulling, its relation to aggression and violence. Based on the point of view of individual authors, the essence and content of the concept of bulling is revealed. Participants of such behavior, the main features of bulling are determined. The aggressive victim was found to be very aggressive and emotionally unstable. In the situation of bullying, it is characterized by a combination of anxious and aggressive reactions, easily irritated and angry, prone to provocation. She is quickly overwhelmed by hostile feelings in a provocative situation, and she becomes unable to correctly interpret intentions or statements. Aggressive victims differ from bullies and humble victims in that they are able to act aggressively, but they do not use them as a tool to achieve the

(C) СОРОЧАН Д.А. - ад’юнкт відділу організації освітньо-наукової підготовки (Харківський національний університет внутрішніх справ) 
goal and do not systematically choose weaker people as the target of aggression, but use it as a result of loss of self-control. Bullying is defined as social, emotional behavior of a person or group of persons, which can be expressed in antisocial aspect, carries verbal and nonverbal ways of expression, where there is a mismatch of power and authority, which puts the victim (victims) in the position in which he (they) unable to defend himself, is long-lasting, the result of which is the onset of negative consequences for the victim (victims) and the satisfaction of their actions by the aggressor (aggressors).

Key words: bulling, aggression, violence, minor.

Вступ. Дослідження поняття булінгу актуальне для України. Агресія неповнолітніх значно зростає, що виражається у знущанні як моральному, так і у фізичному плані над особами такого самого віку, меншого або старшого. Вказаний період життя цих осіб протікає у шкільних закладах, ліцеях, технікумах тощо, де формуються інститути соціалізації особистості, моральні та психологічні властивості неповнолітніх. Цей вік вважається «перехідним». Як родина, так і педагоги часто ігнорують «витівки» школярів, така реакція дорослих осіб призводить до почуття безкарності та вседозволеності у неповнолітніх, надихаючи останніх на нові протиправні пригоди. Крім того, неконтрольований інформаційний простір Інтернету, до якого всі мають доступ, у т. ч. і на будь-які сайти, може негативно впливати на свідомість неповнолітніх, оскільки в цьому віці такі особи мають хитку психіку та можуть неправильно зрозуміти ту чи іншу інформацію або ж тлумачити іiі по-своєму. Все це впливає на поведінку дитини і може викликати агресію щодо інших осіб, тварин, навколишнього середовища.

У нашій статті аналізуються праці деяких вчених, присвячені булінгу. Враховуючи норми чинного законодавства та специфічний суб'єкт, щодо якого вчиняються такі дії за сучасних соціальних умов, дослідження й аналіз булінгу є важливим і необхідним завданням.

Вагомий внесок у вивчення теоретичних і практичних аспектів булінгу зробили С.С. Ілларіонова, К.С. Шалагінова, А.І. Авер'янов, Т.В. Докукіна, Д.А. Лейн, Л.І. Лушпай, І.С. Бердишев, М.Г. Нечаєва, І.С. Кон та ін. Водночас поняття булінгу докладно не розглянуто. Сьогодні в літературі з адміністративного права недостатньо досліджено поняття булінгу, основні його риси й учасники. На усунення цієї прогалини і спрямована стаття.

Постановка завдання. Мета - спираючись на погляди окремих авторів, розкрити особливість поняття булінгу.

Завдання дослідження присвячене вивченню сутності та змісту поняття булінгу, а також його аналізу.

В Україні дотепер не було досліджено сутність і зміст булінгу на монографічному рівні. У статті на основі положень теорії адміністративного права розглядаються сутність і зміст цього поняття.

Результати дослідження. Агресивна поведінка неповнолітніх осіб зазвичай формується в колективному середовищі - серед однолітків, у школах, технікумах, ліцеях тощо. Крім того, така форма поведінки може грунтуватися на інформації з мережі Інтернет, тому що саме в такому віці - «перехідному» - діти мають хитку психіку та можуть взяти собі за приклад жорстокість, агресію і застосовувати їх у своїй поведінці. Також необхідно пам'ятати, що будь-які дії булінгу спричиняють для жертви тяжкі наслідки. Аналізуючи попередні дослідження, можна зауважити, що у багато разів підвищується ризик суїцидальності. Також булінг може виражатися або бути пов'язаним із діяннями, які містять ознаки складів адміністративних правопорушень - булінгом (цькуванням) учасника освітнього процесу (ст. 173-4 КУПАП), що підвищує криміногенну обстановку загалом.

Дедалі частіше засоби масової інформації як у нас у країні, так і за кордоном повідомляють широкій громадськості про ті чи інші надзвичайні пригоди, що трапилися у школі: десь дівчата побили свою однокласницю, десь учня зацькували його ж однолітки, після чого він звів рахунки з життям, а десь розігралася трагедія з перестрілками і численними жертвами. I це, як ми розуміємо, лише вершина айсберга тієї колосальної соціальної проблеми, яку в усьому світі сьогодні називають булінгом.

Термін «булінг» походить від англійського дієслова «to bully». Кембриджський словник англійської мови дієслово «to bully» тлумачить як «ображати, залякувати когось, хто є меншим або менш впливовим ніж ви, часто - примушувати таку особу до небажаних дій» [3].

Оксфордський словник визначає дієслово «to bully» як «прагнути завдати шкоду, залякувати або примусити до небажаної дії уразливу особу або особу, яка сприймається як така» [4]. 
Українською мовою дієслово «to bully» перекладається як цькування, залякування. Булінг (англ. bullying - залякування, цькування) - це систематичне агресивне переслідування і цькування, залякування із застосуванням фізичної сили з метою примусу або домінування [1, с. 248].

Поняття булінгу вивчалося в роботах зарубіжних і вітчизняних дослідників, зокрема таких авторів, як Д. Лейн, Д. Олвеус, Е. Роланд, І. Бердишев, Т. Мерцалова, В.Р. Петросянц, О.Л. Глазман. У роботах І.С. Кона булінг розглядається як залякування, фізичний і / або психологічний терор стосовно дитини з боку групи однолітків. Це форма жорстокого поводження, коли фізично або психічно сильний індивід або група отримує задоволення, завдаючи фізичний або психологічний біль більш слабкій людині.

Одним із перших, хто почав вивчати цю проблему, був скандинавський вчений Девід Олвеус, який провів у 70-х рр. дослідження явища булінгу серед хлопчиків. Відтоді його колеги в багатьох країнах світу всебічно вивчають проблему булінгу, ряд країн на найвищому рівні стурбовані нею, створювалися державні та міжнародні антибулінгові програми. У нашій країні, на жаль, широкомасштабних дій для запобігання цьому явищу не ведеться, хоча останнім часом стали з'являтися наукові публікації на тему булінгу, захищаються дисертації.

Д. Олвеус описує булінг як особливий вид насильства, коли одна людина (або група) фізично нападає або загрожує іншій людині (групі), останній із яких слабший і не може захиститися ні фізично, ні морально.

Особливостями булінгу також $є$ :

a) регулярна повторюваність протягом певного часу;

б) суб'єкти взаємодії («кривдник» і «жертва») зазвичай є представниками однієї і тієї самої соціальної групи [2, с. 23].

Зазначені характеристики дозволяють зрозуміти різницю між булінгом і випадковою бійкою або сваркою, які іноді відбуваються між людьми.

Явище булінгу має такі специфічні особливості:

1) прояв насильницьких, агресивних дій;

2) дії мають тривалий контекст;

3) дії спрямовані на людину, не здатну захиститися;

4) дії булінгу є цілком усвідомленими.

Це саме свідоме насильство, агресор прекрасно усвідомлює і віддає собі повний звіт про те, що він робить, для чого робить і які можуть бути наслідки, тобто булінг - це свідоме заподіяння болю і страждань іншій людині.

Таким чином, термін «булінг» тісно пов'язаний із такими поняттями, як насильство (застосування силових методів або психологічного тиску за допомогою погроз, свідомо спрямованих на слабких або тих, хто не може чинити опір; панування, влада людини над людиною [13, с. 247]), агресія (дії, спрямовані на порушення фізичної та психічної цілісності людини або групи людей) [14]. Агресія органічно пов'язана з насильством і $є$ його природним підгрунтям. Поняття агресії ширше за поняття насильства, воно включає в себе поняття насильства, третирування (виявляти зневагу до когось, поводитися безцеремонно, не зважати на чиюсь думку $[15$, с. 248$]$ ), цькування (переслідувати кого-небудь різними нападками, наклепами і т. ін., знущатися з когось [16, с. 259]). Усі ці поняття відображають різні аспекти такого явища, як булінг. Тобто вищевказані поняття є більш обширними, але у розумінні поведінки агресора при вчиненні булінгу вони відображають діяння агресора.

Як зазначає О.М. Ожиєва, булінг - нове поняття в житті сучасної людини. 3 повсякденного визначення це слово перетворилося в міжнародний термін і містить ряд проблем: соціальних, психологічних, юридичних і педагогічних [5]. 3 висловом вченої ми не можемо повністю погодитися. Безумовно, булінг є великою проблемою у сучасному світі, що негативно впливає на молодь всього світу та нашої країни. Але ми не можемо вважати, що булінг - це щось нове. Новим терміном «булінг» охрестили старе, можна сказати, вікове явище - дитячу жорстокість.

Тому що цькування, залякування осіб, які мають більш слабкий характер, було й раніше. Все це призводить до самогубства, вчинення кримінальних правопорушень проти життя та здоров'я, проти власності. Тобто це додатковий напрям до зростання злочинності проти людей і держави, адже найцінніше що є у державі - це іiі суспільство. Саме тому необхідно підіймати це питання не тільки на рівні своєї держави, а й на міжнародному рівні.

За визначенням Е.С. Іларіонової, булінг - залякування, психологічний або фізіологічний терор, агресія, спрямована на підпорядкування собі іншої людини або викликання у неї почуття страху [6]. На наш погляд, це визначення не має у своєму змісті наслідків такої поведінки 
агресора. Необхідно обов'язково зауважити, що такі дії мають негативні наслідки для жертви. Крім того, першочергово визначається причинний зв'язок між діяннями агресора та настанням негативних наслідків щодо жертви.

У свою чергу, А.І. Авер'янов розглядає булінг як особливий вид насильства, коли одна людина (або група) фізично нападає або загрожує іншій людині (групі), останній із яких слабший i не може захиститися ні фізично, ні морально [7]. Вчений також не говорить про негативні наслідки щодо жертви та причинний зв'язок між діяннями та цими наслідками. На наш погляд, це $\epsilon$ обов'язковим. Якщо до жертви вчиняється булінг із боку декількох сторін (наприклад, у колективі та вдома), то перед усуненням цієї проблеми слід зрозуміти початок таких дій, тобто необхідне встановлення та дослідження початку всієї ситуації та до самого завершення. Це дасть змогу скоріше виявити причину такої поведінки з боку агресора, ії усунення та надання насамперед психологічної допомоги жертві.

Схожість твердження цього явища простежується у праці X. Леймана, котрий визначає буллінг як «соціальну взаємодію, через яку одна людина (іноді декілька) зазнають нападів іншої людини (іноді декількох, але зазвичай не більше чотирьох) майже щодня впродовж тривалого періоду (декількох місяців), що викликає у жертви стан безпомічності та виключення із групи» $[8$, c. 10].

Л. Кішлі вважає, що основною характеристикою булінгу є емоційне приниження, образа почуттів людини, які призводять до виключення іiі з групи. Дослідниця зазначає, що булінг це агресивна поведінка, спрямована приниження почуттів, висловлювання негативних емоцій і принизливих оцінок щодо іншої людини. Булінг не $\epsilon$ порушенням закону, адже у кримінальному кодексі зазвичай немає закону, згідно з яким така поведінка карається [8, с. 12-13].

Схожою $є$ думка Т.В. Докукіної, котра розуміє булінг як агресивну поведінку однієї людини щодо іншої з метою заподіяння останній моральної або фізичної шкоди, приниження і в такий спосіб утвердження своєї влади [9]. Але вчена вказує лише на агресивну поведінку однієї особи щодо іншої, ми з такою позицією не згодні. Вивчивши практику, яка існує в Україні та у світі загалом, стверджуємо, що агресором може виступати як одна особа, так і група осіб, аналогічно і жертвою може виступати як одна особа, так і група.

Найбільш повне визначення, на наш погляд, дали британські дослідники Д. Лейн та Е. Міллер. Вони визначають булінг як довготривалий процес усвідомленого жорстокого поводження, фізичного або психічного, з боку індивіда або групи щодо іншого індивіда, який не здатен захиститися в такій ситуації [10].

C. Arora (1994), досліджуючи ситуацію булінгу в шкільному середовищі, дійшов висновку, що булінгом $є$ певні дії, які піддаються спостереженню і мають місце у спілкуванні між молодими людьми у школі, що є причиною появи почуття образи або стресу [11, с. 14].

B. Besag (1989) припустив також, що булінг - це поведінка, яка може бути визначена як неодноразовий напад - фізичний, психологічний, соціальний або вербальний - тими, чия влада формально або ситуативно вища, на тих, хто не має можливості захиститися, із наміром заподіяти страждання для досягнення власного задоволення [12, с. 110].

Отже, згідно з результатами досліджень булінг - складна проблема. Спробуємо виділити ознаки булінгу:

1) він не $є$ відокремленою поведінкою, заснованою на таких змінних, як статус, влада або конкуренція. Це соціальна поведінка, що проявляється у відносно стійких групах і здатна залучати інших;

2) емоційне приниження включає вербальні (негативно забарвлені висловлювання, використання підвищеного тону, крик, звинувачення у помилках, приниження здобутків і досягнень людини) та невербальні способи вираження (зневажливий погляд, мовчазне засудження, образливі жести тощо);

3) продовження емоційно образливої та принизливої поведінки, ігнорування у колективі впродовж тривалого періоду. Така систематична поведінка агресора сприяє відчуттю самоприниження жертви;

4) втручання у приватне життя людини. Наприклад, якщо агресор принижує або якимсь чином «торкається» приватного життя жертви (слід зауважити, що в нашому випадку жертва це завжди неповнолітня особа, у якої зазвичай психологічний стан хиткий і яка легко піддається на провокаційну поведінку з боку агресора), то такі діяння також слід розцінювати як булінг;

5) якщо наслідком агресивного, негативного ставлення до людини $є$ погіршення психологічного і фізичного стану цієї людини, то така поведінка визначається як булінг; 
6) якщо агресор має намір завдати шкоду іншій людині або дозволяє чи сприяє, щоб ця людина пережила травмуючи події, ця поведінка є булінгом;

7) агресор займає вище становище, ніж його жертва, і відповідно дозволяє собі дії, які принижують гідність і завдають моральної або фізичної шкоди іншій людині.

Таким чином, можемо зробити висновок, що булінг - це соціальна, емоційна поведінка особи або групи осіб, яка може виражатися в антисоціальному аспекті, має вербальні та невербальні способи вираження, де існує невідповідність сили та влади, що ставить жертву (жертв) у становище, у якому вона (вони) не здатна захиститися, має тривалий характер, результатом якого $є$ настання негативних наслідків щодо жертви (жертв) та отримання задоволення від своїх діянь агресором (агресорами).

Дослідження багатьох вчених підштовхує до висновку про те, що особа не народжується зі схильностями до агресивної, жорстокої поведінки щодо інших, а набуває їх у процесі розвитку у суспільстві. Але з таким твердженням можна не погодитися. Безсумнівно, суспільство, в якому народжується, зростає та розвивається індивід, впливає на становлення характеру та поведінки особи. Але чи присутній аспект у особи при народженні саме жорстокості, агресії тощо, який може потім і не мати розвитку? I цей аспект, на нашу думку, потребує додаткових досліджень. Що ж стосується булінгу з погляду адміністративного права, то ми вважаємо, що необхідним $є$ встановлення саме причин, які спонукають агресора до такої поведінки.

Отже, мотивація до булінгу може бути різною: помста, відновлення справедливості, інструмент підкорення лідерові, почуття неприязні, бажання самоствердження тощо. Особливо небезпечною є мотивація, пов'язана із задоволенням садистичних потреб у певної категорії акцентованих особистостей [17].

Крім того, серед причин булінгу в колективі вчені виділяють: боротьбу за лідерство; зіткнення різних субкультур, цінностей, поглядів і невміння толерантно ставитися до них; агресивність і віктимність; наявність у дитини психічних і фізичних вад; заздрість; відсутність предметного дозвілля тощо [18, с. 196].

Неможливо створити вичерпний перелік причин, із яких відбувається булінг. Вони можуть бути різноманітні або ж їх може взагалі не бути, оскільки неповнолітні особи мають «не встановлений» характер і поведінку, які постійно змінюються.

Також необхідно розуміти, як саме вчиняється булінг. Його можна поділити за формами вираження.

Деякі вчені розрізняють прямий і непрямий булінг. До прямого булінгу відносять: удар, штовхання, щипання, плювання, кусання, залякування, обзивання, жорстокі жарти, утискання через соціальний статус, релігію, расу, доторки сексуального характеру [19-21]. Непрямий булінг проявляється переважно у емоційній і пасивно агресивній поведінці, яка включає ізоляцію, виключення, поділ на категорії нижче і вище, ненависний погляд, непристойні жести, графіті, поширення пліток, зловживання стосунками, вимагання грошей чи речей [20;21].

На наш погляд, більш правильно розподілити форми вираження булінгу серед неповнолітніх осіб на такі основні види, як:

1) фізичний булінг - умисні удари, стусани, побої, нанесення інших тілесних ушкоджень тощо; сексуальний булінг, хепіслепінг (від англ. happy slapping - щасливе ляскання). Останній відносно новий вид кібербулінгу, який починався в англійському метро, де підлітки, прогулюючись пероном, раптом ляскали один одного, тоді як інший учасник знімав цю дію на мобільну камеру. Надалі за будь-якими відеороликами, в яких записано реальні напади, закріпилася назва хепіслепінг. Ці відеоролики розміщують в Інтернеті, де їх можуть продивлятися тисячі людей, зазвичай без жодної згоди жертви. Інша форма хепіслепінгу - це передавання сюжетів через мобільні телефони. Починаючись як жарт, хепіслепінг може завершитися трагічно, наприклад, як це сталося із 18-річним Трістоном Крістмасом, якого група хлопців побила, аби зняти відео для Інтернету, а коли він, вдарившись головою, помирав, кинутий на підлозі, вбивця і спостерігачі пішли продовжувати вечірку. 3'явилося навіть поняття «буліцид»-загибель жертви внаслідок булінгу, вважається злочином і хепіслепінг, якщо він призводить до таких трагічних наслідків [22];

2) психологічний булінг - насильство, пов'язане з дією на психіку, що завдає психологічної травми через словесні образи або погрози, переслідування, залякування, якими навмисно заподіюється емоційна невпевненість. До цієї форми належать вербальний булінг (знаряддям слугує голос (образливе ім'я, з яким постійно звертаються до жертви, обзивання, поширення образливих чуток і т. д.); образливі жести або дії; залякування (використання агресивної мови тіла й інтонацій голосу, щоб змусити жертву здійснювати або не здійснювати що-небудь); ізоляція 
(жертву навмисне ізолює, виганяє або ігнорує частина учнів або весь клас); активне неприйняття (виникає у відповідь на ініціативу, яка походить від жертви, кривдники дають зрозуміти, що

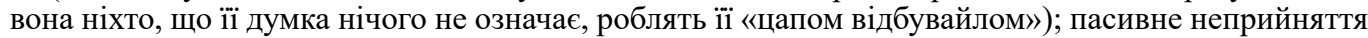
(виникає лише в певних ситуаціях, коли треба вибрати когось у команду, групу, сісти за парту, прийняти до гри, діти відмовляються: «3 ним не буду!»); ігнорування (не звертають уваги, не спілкуються, не помічають, забувають, не проявляють відкритої агресії, але й не цікавляться); вимагання (грошей, їжі, інших речей); пошкодження та інші дії з майном (крадіжка, грабіж, ховання особистих речей жертви); кібербулінг (приниження за допомогою мобільних телефонів, Інтернету, інших електронних пристроїв (пересилання неоднозначних зображень і фотографій, обзивання, поширення чуток тощо)).

Учасників булінгу можна розділити на три групи:

1) булери - це особи, котрі мають соціальну вагу або наділені більшою фізичною силою, з високим потенціалом агресивності, спрямованої на інших індивідів;

2) жертви - це особи, які є об'єктами знущань. Ця категорія додатково поділяється на покірних і агресивних жертв. Покірні жертви більш тривожні та невпевнені, ніж звичайні особи (учні, студенти тощо), і виявляють тенденцію бути більш обережними, сензитивними, схильними замикатися в собі. Їхня типова реакція на булінг полягає не в тому, щоб чинити опір, а в тому, щоб спробувати уникнути мучителів. Їм властиве негативне ставлення до себе, вони можуть перебувати у самотності, не проявляти агресії та віддалятися від колективу. Покірні жертви страждають від низького почуття власної гідності, часто уявляють себе невдахами, дурними, сором'язливими і непривабливими людьми.

Агресивну жертву описують дуже агресивною й емоційно нестабільною. У ситуації булінгу вона характеризуються комбінацією з тривожних і агресивних реакцій, легко дратується і впадає у стан гніву, піддається на провокації. Іїі швидко охоплюють неприязні почуття у провокаційній ситуації, вона стає не здатною правильно інтерпретувати наміри або висловлювання. Агресивні жертви відрізняються від булерів і покірних жертв тим, що здатні проявити агресивні дії, але не використовують їх як інструмент для досягнення мети та не вибирають систематично для агресії більш слабких осіб, а вдаються до неї внаслідок втрати самовладання.

Агресивні жертви схильні до зниження самооцінки, низького ступеня соціальної підтримки. Це вкрай важливо, тому що така підтримка має буферизувати ефект у напруженій ситуації і допомагає впоратися з нею [25];

3) спостерігачі (свідки) - це особи, що спостерігають за булінгом. У свою чергу, спостерігачів розподіляють на тих, які надають допомогу (допомагають булеру, але безпосередньо не здійснюють агресивних дій, закликають для подальшого насильства однолітків, що оточують їх); посилювачів (відіграють лише не значну роль у булінгу, наприклад, вони можуть сміятися над образами кривдника); аутсайдери (випадкові спостерігачі, які зовсім не беруть участі у булінгу, але $\epsilon$ свідками); відповідачів (безпосередньо залучені для захисту або втішання жертви після знущань) [23, с. 152; 24].

У 2018 р. в українських школах зафіксували близько 109 тис. звернень до психологів через цькування. До фахівців зверталися як самі учні, так і батьки з учителями. Як зазначається, $39 \%$ з усіх звернень надходили від дітей, 29\% - від вчителів, ще 5\% - від сторонніх людей, решта від батьків [26].

Дитячий фонд ООН ЮНІСЕФ підрахував, що за 2018 р. 67\% українських школярів стикалися $з$ проблемою булінгу, і щороку бійки між дітьми стають дедалі частішими та жорстокішими. За 2017 р. чверть (24\%) дітей в Україні стали жертвами булінгу (цькування) у школах, майже половина (40\%) потерпілих не ділилися цим ні з ким. У підлітковому віці цькувань зазнали більше третини учнів.

Згідно зі звітом фонду «Щоденний урок: Зупинити насильство у школах» дівчатка частіше піддаються психологічному тиску, тоді як хлопчики страждають від фізичного насильства [27].

За результатами анкетування, проведеного Міністерством юстиції України, приниження у школі зазнавало $45 \%$ опитаних дітей у Закарпатській області, половина опитаних школярів Київської області, більше половини юних одеситів були свідками чи жертвами булінгу в школі. Серед чернівецьких школярів морального приниження хоч раз у житті зазнавали $48 \%$ учнів; фізичного кривдження $-27 \%$; нападу з боку групи - $14 \%$; пограбування $-12 \%$; сексуальної загрози $-8 \%$ опитаних [28].

Нами було проведене дослідження серед восьмикласників в одній із Харківських шкіл, яке показало такі результати: $15 \%$ опитаних вважають, що насильство у школі відсутнє, 33\% від- 
повіли, що насильство спостерігається дуже рідко у їхній школі, 25\% відповіли, що насильство в школі має середню поширеність, 27\% вважають, що насильство дуже поширене. 86\% підлітків зазначили, що спостерігали явище булінгу в школі. Переважна більшість опитаних зіштовхувалася зі словесними приниженнями, образами, глузуванням, використанням прізвиськ - 45\%, 32\% опитаних спостерігали побиття, ляпаси, штовхання, 23\% спостерігали словесні натяки сексуального характеру.

На запитання: «Де, на Ваш погляд, підлітки найчастіше стикаються з проявами булінгу?» були отримані такі відповіді: 11\% респондентів вважають, що найчастіше підлітки зазнають насильства по дорозі до школи, 37\% назвали місцем насильства вулицю біля школи, 42\% - шкільний коридор, $5 \%$ - шкільний туалет, 5\% - шкільну їдальню.

За даними 25\% респондентів, найчастіше агресорами є однолітки, 21\% дітей сказали, що це група однолітків, по 32\% - старшокласник і група старшокласників.

$58 \%$ респондентів зазначили, що найчастіше агресорами є хлопці, 42\% учнів відповіли, що агресорами є дівчата. Жертвами шкільного насильства, за отриманими даними, у 68\% випадків є хлопці, у $32 \%$ - дівчата.

За отриманими результатами, педагоги по-різному реагують на випадки булінгу: 53\% школярів відповіли, що педагоги вимагають припинення сварок, приниження; 33\% підлітків вважають, що педагоги не звертають уваги на такі випадки; 14\% - що педагоги покладають вирішення проблеми на самих учнів, не втручаючись у їхні стосунки. 37\% учнів вважають ефективними такі заходи 3 попередження явища булінгу, як бесіди класного керівника з учнями; 26\% - залучення шкільного психолога; 32\% - залучення працівників правоохоронних органів; 5\% - заходи із залученням фахівців громадських організацій.

Висновки. На підставі вищевикладеного можна констатувати, що актуальність дослідження булінгу є очевидною. Булінг, який вчиняється серед неповнолітніх осіб, ще більш стає небезпечним для суспільства та держави загалом. Ми виділили основні його риси, причини вчинення та виокремили коло суб'єктів, які так чи інакше стають учасниками булінгу.

Крім того, після аналізу статистичних даних організацій і проведення анкетування у Харківській школі стає очевидною нагальна необхідність у таких заходах, як профілактика булінгу в школі з метою зниження рівня агресії, насильства, цькування, приниження серед підлітків і попередження злочинності неповнолітніх.

\section{Список використаних джерел:}

1. Словник іншомовних слів / за ред. О.С. Мельничука. Київ : Головна редакція «Українська радянська енциклопедія» (УРЕ), 1974. 776 с.

2. Аверьянов А.И. Школьный буллинг в воспоминаниях студентов МГПИ. Современные проблемь и пути их решения в науке, транспорте, производстве и образовании : Материалы междунар. научн.-практ. конф. Вып. 4. Т. 15. Одесса, 2011. С. 22-26. $\mathrm{ru} /$ bully.

3. Meaning of "bully" in the Cambridge Dictionary. URL: https://dictionary.cambridge.org/

4. Main definicions of bully in English. URL: https:/www.lexico.com/en/definition/bully.

5. Ожиева Е.Н. Буллинг как разновидность насилия. Школьный буллинг. URL: http://www.rusnauka.com/33_NIEK_2008/Psihologia/3 7294.doc.htm.

6. Илларионова Е.С., Шалагинова К.С. Проблема буллинга в подростковом возрасте. $M a-$ териаль V Международной студенческой электронной научной конференции «Студенческий научный форум». URL: http:www.scienceforum.ru/2013/178/2003.

7. Аверьянов А.И. Буллинг как вызов современной школе. URL: http:/www.sworld.com.ua/ konfer30/531.pdf.

8. Randall P. Bullying in Adulthood: Assessing the Bullies and Their Victims. Florence, KY, USA: Brunner-Routledge, 2001. URL: http:/site.ebrary.com/lib/bckharkiv/Doc?id=10053591.

9. Докукина T.B. Буллинг - травля в школе URL: http://belasma.gippokrat.bv/bottom news block/children/bulling-vshkolah/index.htm.

10. Лейн Д.А. Шкільна травля (булінг). URL: http://www.zipsites.ru/psy/psyib/info.php?=414.

11. Arora C.M.J. Measuring bullying with the life in School checklist. Patoral Care in Education. 1994. № 12. P. 11-15.

12. Besag V.E. Bullies and Victims in Schools. Milton Keynes : Open University Press. 1989.232 p.

13. Чепи Л.А. Українська психологічна термінологія : словник-довідник. Київ : ДП «Інформ.- аналіт. агентство», 2010. 
14. Лушпай Л.І. Шкільний буллінг як різновид суспільної агресії. Наукові записки Наи. ун-ту «Острозька академія». Серія: Філологічна. 2013. Вип. 33. С. 85. URL: http://nbuv.gov.ua/ j-pdf/Nznuoaf_2013_33_28.pdf.

15. Словник української мови : в 11 т. Т. 10. 1979. С. 248.

16. Словник української мови : в 11 т. Т. 11. 1980. С. 259.

17. Бердышев И.С., Нечаева М.Г. Медико-психологические последствия жестокого обращения в детской среде. Вопросы диагностики и профилактики. Практическое пособие для врачей и социальных работников. Санкт-Петербургское государственное учреждение социальной помощи семьям и детям «Региональный центр “Семья"», 2005. URL: http:/www. homekid.ru/ bullying/contens.html.

18. Система захисту дітей від жорстокого поводження : навчально-методичний посібник / Л. Волинець, Т. Дорошок, М. Свсюкова та ін. ; ред. : К. Левченко, І. Трубавіна ; Держ. соц. служба для сім'ї, дітей та молоді. Міжнар. жіночий правозахисн. центр «Ла Страда Україна». Київ : Держсоцслужба, 2005. 395 с.

19. Кон И.С. Что такое буллинг и как с ним бороться? Семья и школа. 2006. № 11. С. 15-18. URL: http://www.pseudology.org/Kon/Zametki/ ChtoTakoeBulling.htm.

20. Quiroz H. Bullying in Schools. Fighting the Bully Battle. Discussion Activities for School Communities. National School Safety Center, 2006. URL: https://www.academia.edu/9988486/ Bullying_In_Schools_Fighting_the_Bully_Battle_Discussion_Activities_for_School_Communities National School Safety Center.

$2 \overline{1}$. Quiroz H. Bullying in Schools. Fighting the Bully Battle. Bullying Fact Sheet Series. National School Safety Center, 2006. URL: http://teachingconditions.org/archives/566.

22. Інтернет ресурс. Кібербулінг: новітні небезпеки в інтернет-просторі. URL: https://glavcom.ua/specprojects/stopbullying/kiberbuling-novitni-nebezpeki-v-internetprostori-460488.html.

23. Петросянц В.Р. Проблема буллинга в современной образовательной среде. Вестник ТГПУ. 2011. Вып. 6 (108).

24. Sholl bulling. URL: https://en.wikipedia.org/wiki/School_bullying.

25. Björkqvist K., Ekman K., Lagerspetz K. Bullies and their victims: Their ego picture, ideal ego picture and normal ego picture. Scandinavian Journal of Psychology. 1982. № 23. P. 307-313.

26. Інтернет ресурс. Булінг у школі. URL: https://www.5.ua/suspilstvo/torik-v-ukraininarakhuvaly-maizhe-110-tys-zvernen-pro-bulinh-175437.html.

27. Інтернет ресурс. UA.NEWS. URL: https://ua.news/ua/oon-opublikuvav-nevtishnustatistiku-bulingu-v-ukrayinskih-shkolah/.

28. Богуславська А. Насильство у школі. URL: http://www.umoloda.kiev.ua/number/ $904 / 171 / 32933 /$. 